\title{
Dermatologic Complication
}

National Cancer Institute

\section{Source}

National Cancer Institute. Dermatologic Complication. NCI Thesaurus. Code C115209.

Any skin disorder occurring as a consequence of injury to the skin tissue. 